DOI: $10.1515 / \mathrm{rrlm}-2016-0035$

\title{
Serum level of apelin-13 negatively correlated with NT-proBNP in heart failure patients
}

\author{
Nivelul seric al apelin-13 este corelat negativ cu NT-proBNP \\ la pacienții cu insuficiență cardiacă
}

\author{
Cerasela Mihaela Goidescu ${ }^{1, *}$, Florin Petru Anton1, Daniel Corneliu Leucuța ${ }^{2}$, \\ Petru Adrian Mircea ${ }^{1}$, Luminița Animarie Vida-Simiti ${ }^{1}$ \\ 'Department of Internal Medicine, Cardiology and Gastroenterology, $1^{\text {st }}$ Medical Clinic, UMF "Iuliu \\ Hațieganu” Cluj-Napoca, Romania, \\ ${ }^{2}$ Medical Informatics and Biostatistics Department, UMF "Iuliu Haţieganu” Cluj-Napoca, Romania
}

\begin{abstract}
Background: Apelin is a potent endogenous inotropic peptide with a major role in counteracting the aldosterone and angiotensin II and their negative effects on the cardiovascular system. The exact role of apelin in the pathophysiology of this disease is not well understood. We aimed to investigate the possible associations of apelin-13 with clinical and paraclinical characteristics in HF patients as well as studying its dynamics during the course of the heart failure. Method: We performed a prospective observational cohort single-center study. We compared the baseline serum levels of apelin-13 and NT-proBNP level in 53 heart failure patients (acute heart failure, chronic compensated heart failure and chronic decompensated heart failure). We divided the patients according to the apelin-13 level: above and below the median, and we analyzed the relationship between serum apelin-13 and the clinical, echocardiographic, electrocardiographic and biological parameters. Twenty patients were followed-up (after an average time interval of 9 months), investigating the same parameters. Results: The median of apelin-13 was 495pg/mL (IQR 276-845pg/mL). We found strong, negative correlation between the serum levels of apelin-13 and NT-proBNP (Spearman $r h o=-0.83, p<0.001$ ). For the reassessed patients the median apelin level was significantly higher at follow-up $(460 \mathrm{pg} / \mathrm{mL}, I Q R$ 342-871 pg/mL) as compared with the baseline level (395 pg/mL, IQR $270-603 \mathrm{pg} / \mathrm{mL}$ ), $p=0.019$, and maintained the negative correlation with NT-proBNP level (Spearman's rho -0.7, $p<0.001$. The Low Apelin-13 group have higher NT-proBNP levels and also contains all the patients in NYHA IV class heart failure, $71 \%$ of the acute HF patients, and 7 of 8 patients who died before follow-up. Conclusion: Apelin-13 was negatively correlated with NT-proBNP. The Low Apelin-13 group contained the majority of the patients with a negative outcome (death before follow-up), most of the patients who presented with acute HF and all the patients in NYHA IV class.
\end{abstract}

Keywords: heart failure; apelin;NT-proBNP; peptide.

* Corresponding author: Cerasela Mihaela Goidescu, Department of Internal Medicine, Cardiology and Gastroenterology, ${ }^{\text {st }}$ Medical Clinic, UMF "Iuliu Hațieganu” Cluj-Napoca, Clinicilor 3-5, Cluj-Napoca, Romania, e-mail: ceraselagoidescusava@yahoo.com 


\section{Rezumat}

Introducere: Apelinul este un peptid endogen inotrop pozitiv cu rol important in contrabalansarea aldosteronului și angiotensinei II și limitarea efectelor negative ale acestora. Nivelul apelinului se reduce pe parcursul evoluției insuficienței cardiace însă rolul său exact în fiziopatotologia bolii nu este încă cunoscut. Scopul studiului a fost de a investiga posibila asociere dintre nivelul seric al apelin-13 și caracteristicile clinice și paraclinice ale pacienților cu IC, precum și analiza modificărilor lui pe parcursul bolii. Metodă: Am efectuat un studiu de cohortă, prospectiv, intr-un singur centru. Au fost incluși 53 de pacienți cu insuficiență cardiacă (insuficiență cardiacă acută, cronică compensată și cronică decompensată) la care s-au comparat nivelele serice ale apelin-13 și NT-proBNP. În funcție de mediana apelin-13 pacienții au fost împărțiți în două grupuri: apelin-13 mai mare și respectiv mai mic decât mediana, și s-a analizat relația dintre nivelele apelin-13 și caracteristicile clinice, ecocardiografice, electrocardiografice și biologice ale pacienților. Douăzeci de pacienți au fost reevaluați după un interval mediu de timp de 9 luni, analizând aceiași parametri. Rezultate: Valoarea mediană a apelin-13 a fost 495pg/mL (IQR 276-845pg/ $m L$ ). Rezultatele au arătat că apelinul este strâns și negativ corelat cu nivelul NT-proBNP (coeficient Spearman's rho $=-0.83, p<0.001)$. La pacienții reevaluați nivelul apelin-13 a crescut semnificativ (460 pg/mL, IQR 342-871 pg/ $m L)$ comparativ cu nivelul bazal (395 pg/mL, IQR 270-603 pg/mL), p=0.019, și a menținut corelația negativă cu NT-proBNP (coeficient Spearman's rho -0.7, $p<0.001$. În grupul cu Apelin-13 scăzut au fost prezenți toți pacienții în clasa NYHA IV, 71\% din cei cu IC acută și 7 din 8 pacienți care au decedat inainte de reevaluare. Concluzie: Apelin-13 este corelat negativ cu NT-proBNP. Grupul cu Apelin-13 scăzut a conținut majoritatea pacienților cu evoluție nefavorabilă (deces înainte de reevaluare) și a celor cu IC acută, precum și toți pacienții încadrați în clasa NYHA IV.

Cuvinte cheie: insuficiența cardiacă, apelin, NT-proBNP, peptide.

Received: 02 ${ }^{\text {th }}$ June 2016; Accepted: 23 ${ }^{\text {th }}$ September 2016; Published: $26^{\text {th }}$ September 2016.

\section{Background}

The heart failure is a severe, progressive disease, with a rising incidence around the world due to the prolonged life span and ageing of the world population. It is a particular epidemiological problem in the developed countries where its incidence is about $1-2 \%$ from the whole population and up to $10 \%$ in the population above the age of 70. Besides its increasing incidence, its poor prognosis is another concern. Although there is an increasing number of treatment options for cardiovascular diseases and in particular for heart failure patients, the prognosis for this disease remains more severe than for malignancies [1-7].

The progressive pathophysiology of heart failure is, at least in part, secondary to over-expression of some molecular pathways; they are chronically activated by the impaired tissue perfusion and their purpose is to rise the cardiac output, but in the end it leads to severe injuries of the heart, vessels and kidneys. The best known mo- lecular systems involved in heart failure pathophysiology are the renin-angiotensin-aldosterone system (RAAS) and the adrenergic nervous system (ANS); their chronical stimulation produces a cascade of molecular changes in the myocardium and endothelium, some of which are meant to compensate for the injurious effects of RAAS and ANS. The apelin and its receptor (APJ receptor) is one of the molecular systems which counteracts the negative effects of aldosterone on the myocardial cells and limits the inflammatory reactions and the oxidative stress that are increased in chronic, severe, heart failure. Although apelin is also synthesized in the adipose tissue and was listed as adipocytokine and studied as one [8-11], its major site of synthesis and target is the endothelium and the cardiovascular system. It is the most potent endogenic positive inotropic agent and is a positive regulator of angiotensin converting enzyme type 2, and so it is a RAAS antagonist $[12,13]$. Experimental studies conducted so far have attributed apelin a protective role on 
the cardiovascular system, but also on the nervous system, liver, pancreas and kidneys [14-16]. It seems to be a guardian of the living organism, human or animal, which regulates basic functions of the systems and tissues, helps in the process of recovery after an injury and appears to delay the onset of diseases. Although some of the results reported so far give apelin anti-inflammatory properties, the exogenous administration of apelin being able to lower the inflammatory factors such as tumor necrosis factor $\alpha(\mathrm{TNF} \alpha)$ and interleukin $1 \beta$ (IL-1 $\beta)[17,18]$, its level being increased after lowering the cholesterol level by dietary or pharmacological measures [19] or being in reverse relationship with the level of inflammation in the body [8], other studies do not have such clear results about its relationship with the inflammatory markers $[20,21]$. This is probably due to the complex actions exerted by apelin and its receptor in vivo compared with in vitro conditions.

The plasmatic level of apelin is known to progressively decrease during the course of heart failure after an initial rise in the early stages of the disease [15]. These dynamics are considered to be an attempt to compensate and increase the contractile force of the failing heart [22], but these effects are progressively altered in the course of heart failure. These assumptions were made after observing the effects of experimental iv administration of apelin to animals and humans with heart failure: it acts as a potent inotrope and increases the contractility of the heart, the ejection fraction and the cardiac output and lowers the left ventricle diastolic pressure . These effects were described initially on isolated hearts on which apelin exerted a clear inotropic effect, especially on failing myocardium [23, 24], and then were reproduced on healthy and heart failure human volunteers $[25,26]$. All these scientific results are proof of the beneficial role of apelin in the human body and in particular in the functioning of the cardiovascular system but it suggests its limited protective effect until it is overcome by the injurious molecular pathway and its tissular and serum level begin to fall.

Apelin-13 is the shortest fragment derived from preproapelin and it is the most potent peptide from all the fragments cleaved by angiotensin-converting enzyme from this 77-aminoacid protein; its action is 8 times higher than apelin-17 and 60 times higher than apelin-36 and it is the main biological activator of the APJ receptor. Its pyroglutamated form was found to be the predominant form of myocardial apelin in the human heart and plasma [27-30].

In our research we aimed to investigate the possible associations of apelin-13 with clinical and paraclinical characteristics in HF patients as well as studying its dynamics during the course of the heart failure.

\section{Method}

\section{Patients}

We enrolled 53 patients consecutively admitted for heart failure in the Cardiology Department of our hospital between November 2014 and March 2016. The diagnosis of acute heart failure was made after clinical evaluation, NT-proBNP determination and echocardiographic examination. We included only the patients with heart failure secondary to ischemic heart disease or dilative cardiomyopathy. We excluded the patients with acute coronary syndromes, uncontrolled arterial hypertension, severe valvular diseases (except mitral regurgitation and tricuspid regurgitation secondary to ventricular and valvular ring dilation), diabetes mellitus, severe renal disease (creatinine clearance $<35 \mathrm{ml} / \mathrm{min}$ ), known malignancies, acute viral or bacterial infections.

A control group was formed with 13 patients from the same center, with controlled essential hypertension and no other cardiovascular pathologies, treated with beta-blockers and/or ACE inhibitors. 


\section{Study protocol}

We performed a prospective observational cohort single-center study. The patients were examined at two different moments in time: the clinical, laboratory and echocardiographic assessments were performed at the first hospital admission and again after a time interval of 6-12 months.

Clinical (demography, smoking status, alcohol consumption, personal and familial medical history, blood pressure), biological (blood count, $\mathrm{C}$ reactive protein, liver enzymes, uric acid, cholesterol and its fraction, triglycerides, creatinine clearance, $\mathrm{MB}$ creatinine kinase) and echocardiographic characteristics, (left ventricle (LV) systolic diameters and volumes, ejection fraction (EF\%), global or regional wall motion abnormalities, the presence or absence of severe mitral regurgitation or pulmonary arterial hypertension) were recorded for all patients and used to assess the exclusion criteria. We also noted the type of heart failure at baseline for each patient (acute heart failure, chronic decompensated and chronic compensated heart failure, according to the terminology used by the European Society of Cardiology for the time course related characteristics of heart failure [31]).

All the patients were treated according to the severity of their disease and the guidelines recommendations for acute heart failure with ACE inhibitors, beta-blockers and diuretics.

The study obtained approval from the Bioethics Commission of the University of Medicine and Pharmacy "Iuliu Hațieganu", Cluj-Napoca (No. 377/03NOV2014).

\section{Echocardiography}

Two dimensional echocardiographic examinations were performed for all patients using a Siemens Acuson X300 by the same investigator. The quantitative measurements of the LV dimensions and functional parameters were performed in conformity with the recommendations of the
American Society of Echocardiography (ASE) [32]. The EF\%, LV end-diastolic and end-systolic volumes were calculated using the Simpson biplan method. The LV mass was calculated from end-diastolic LV internal diameter, interventricular septum and posterior wall dimensions using the ASE formula [33, 34], and indexed for body surface calculated with the Dubois formula.

\section{Serum Apelin and NT-proBNP determination}

A sample of serum was collected from each patient and then stored at $-80^{\circ}$. For a homogeneous evaluation of the NT-proBNP for all the patients, its determination was made using the commercial ELISA kit from Cloud-Clone Corp, Houston, USA, with adetectionragebetween $39-2500 \mathrm{pg} / \mathrm{ml}$, an intra-assay coefficient of variability (CV) of $<10 \%$ and an inter-assay $\mathrm{CV}<12 \%$ ).

The serum levels of apelin-13 were assayed using commercially available ELISA kit from Elabscience, Wuhan, China, with a detection range of $125-8000 \mathrm{pg} / \mathrm{ml}$ and an intra and inter-assay $\mathrm{CV}<10 \%$.

\section{Statistical analyses}

The statistical analyses were performed using $\mathrm{R}$ environment for statistical computing and graphics, version 3.2.3 [35]. The normally distributed continuous variables were presented as mean \pm $\mathrm{SD}$ and those not normally distributed were presented as median and 25th and 75th percentile (interquartile range, IQR).

According to the baseline median apelin-13 level, two groups of patients were formed: High Apelin-13 level (above the median) and Low Apelin-13 level (below the median). There were also additional groups formed according to the type of heart failure (acute, chronic compensated and chronic decompensated heart failure) and according to the $\mathrm{EF} \%(>36 \%, 30-35 \%, 25-29 \%$ and $<25 \%)$.

To assess relationships between two categorical variables we used the Chi square test or the Fisher exact test (for low expected values). 
Table 1. The baseline characteristics of patients and controls

\begin{tabular}{|c|c|c|c|c|}
\hline & & Patients $(n=53)$ & Controls $(n=13)$ & P-value \\
\hline \multicolumn{2}{|l|}{ Age (years) } & $67.94(11.81)$ & $55.38(10.69)$ & $<0.001$ \\
\hline \multicolumn{2}{|l|}{ BMI $\left(\mathrm{kg} / \mathrm{m}^{2}\right)$} & $26.2(24.2-30)$ & $29.38(26.6-30.37)$ & 0.273 \\
\hline \multicolumn{2}{|l|}{ Sex (female) } & $15(28.3)$ & $9(69.23)$ & 0.01 \\
\hline \multicolumn{2}{|l|}{ Cigarette smoking } & $15(28.3)$ & $4(30.77)$ & 1 \\
\hline \multicolumn{2}{|l|}{ Alcohol drinking } & $10(18.87)$ & $2(15.38)$ & 1 \\
\hline \multirow{3}{*}{ Heart failure } & Acute (de novo) HF & $14(26.42)$ & & \multirow{3}{*}{-} \\
\hline & Chronic compensated HF & $19(35.85)$ & - & \\
\hline & Chronic decompensated HF & $20(37.74)$ & & \\
\hline \multirow{3}{*}{ NYHA class } & II & $25(47.17)$ & & \multirow{3}{*}{-} \\
\hline & III & $19(35.85)$ & & \\
\hline & IV & $9(16.98)$ & & \\
\hline \multirow{4}{*}{ Medication } & Betablocker & $2(3.77)$ & $1(7.69)$ & \multirow{4}{*}{0.185} \\
\hline & ACE inhibitor & $11(20.75)$ & $0(0)$ & \\
\hline & Betablocker + ACE inhibitor & $28(52.83)$ & $7(53.85)$ & \\
\hline & None & $12(22.64)$ & $5(38.46)$ & \\
\hline \multicolumn{2}{|l|}{$\begin{array}{l}\text { LV end-diastolic } \\
\text { volume }(\mathrm{ml})\end{array}$} & $146(120-190)$ & - & - \\
\hline \multicolumn{2}{|l|}{ LV mass $\left(\mathrm{g} / \mathrm{m}^{2}\right)$} & $162.5(41)$ & $90.6(17)$ & $<0.001$ \\
\hline \multicolumn{2}{|c|}{ Ejection fraction $(\%)$} & $25(20-35)$ & $55(55-60)$ & $<0.001$ \\
\hline \multirow{3}{*}{$\begin{array}{l}\text { Mitral } \\
\text { regurgitation }\end{array}$} & Absent/mild & $15(28.3)$ & $13(100)$ & \multirow{3}{*}{$<0.001$} \\
\hline & Moderate & $18(33.96)$ & $0(0)$ & \\
\hline & Severe & $20(37.74)$ & $0(0)$ & \\
\hline \multirow{4}{*}{$\begin{array}{l}\text { Pulmonary arterial } \\
\text { hypertension }\end{array}$} & Absent & $25(47.17)$ & $13(100)$ & \multirow{4}{*}{0.007} \\
\hline & Mild & $12(22.64)$ & $0(0)$ & \\
\hline & Moderate & $12(22.64)$ & $0(0)$ & \\
\hline & Severe & $4(7.55)$ & $0(0)$ & \\
\hline \multicolumn{2}{|c|}{ QRS duration $(\mathrm{msec})$} & $120(80-140)$ & $80(80-100)$ & 0.012 \\
\hline \multicolumn{2}{|c|}{ NT-proBNP (pg/mL) } & $1241(875-1531)$ & $254(100-334)$ & $<0.001$ \\
\hline \multicolumn{2}{|c|}{ Apelin-13 (pg/mL) } & $495(275-845)$ & $515(402-1005)$ & 0.223 \\
\hline \multicolumn{2}{|c|}{ Uric acid $(\mathrm{mg} / \mathrm{dL})$} & $7.5(6.5-8.9)$ & $4.6(3.8-5.2)$ & $<0.001$ \\
\hline \multicolumn{2}{|c|}{ Total cholesterol (mg/dL) } & $155(140-174)$ & $212(181-219)$ & $<0.001$ \\
\hline \multicolumn{2}{|c|}{ LDL-cholesterol (mg/dL) } & $93(72-106)$ & $135(109-157)$ & $<0.001$ \\
\hline \multicolumn{2}{|c|}{ HDL-cholesterol (mg/dL) } & $41(34-48)$ & $50(41-62)$ & 0.047 \\
\hline \multicolumn{2}{|c|}{ Triglycerides $(\mathrm{mg} / \mathrm{dL})$} & $108(87-144)$ & $89(69-112)$ & 0.116 \\
\hline \multicolumn{2}{|c|}{ C reactive protein $(\mathrm{mg} / \mathrm{dL})$} & $0.5(0.4-0.8)$ & $0.5(0.3-0.5)$ & 0.142 \\
\hline \multicolumn{2}{|c|}{ Creatinine Clearance $(\mathrm{mL} / \mathrm{min})$} & $72.73(32.87)$ & $103.89(23.54)$ & 0.002 \\
\hline Corrected Creatinir & ne Clearance $\left(\mathrm{mL} / \mathrm{min} / 1,73 \mathrm{~m}^{2}\right)$ & $65.65(26.08)$ & $97.54(19.92)$ & $<0.001$ \\
\hline
\end{tabular}


To check for differences between two independent groups of continuous data, the t-test for independent samples (for data following the normal distribution) the Mann Whitney U test was used (for skewed data). Normality of the data was checked with quantile-quantile plot and Shapiro-Wilk test. Comparisons between three or more independent groups regarding continuous variables were made with the Kruskal Wallis test for skewed data. We compared baseline and follow-up meassurements for skewed continous data with Wilcoxon signed-rank test.

To evaluate the association between NT-proBNP and apelin-13 the Spearman correlation coefficient, the test of statistical significance and the 95\% confidence interval (CI- calculated by bootstrapping) and a scatter plot chart type were used.

A multiple linear regression model was built to assess the relation between initial val- ues of NT proBNP as dependent variable and apelin, adjusted for age, gender, LDL and HDL cholesterol, and BMI corrected clearance. The model was verified for normality of residuals, heteroskedasticity, multicolinearity. The results are presented by model coefficients and robust confidence intervals (CI -computed using the sandwich estimators).

For all statistical tests the two tailed P-value was computed, and the level of statistical significance was set as 0.05 .

\section{Results}

\section{Baseline assessment}

The baseline characteristics of the patients and the control subjects are described in Table 1. The median value of apelin-13 in the group of patients and controls was $495 \mathrm{pg} / \mathrm{mL}$ (IQR 276-845 pg/mL)

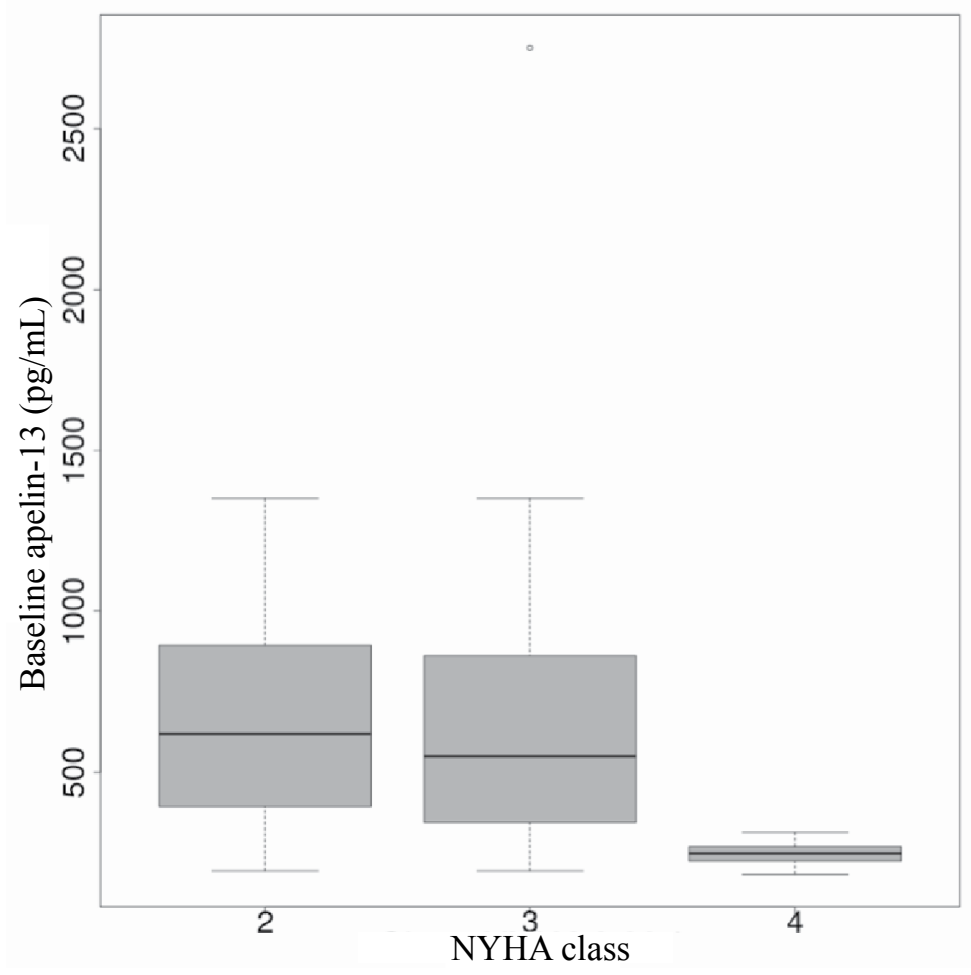

Figure 1. The level of apelin-13 between the NYHA class groups, at baseline. 
Table 2. The baseline apelin-13 level in the heart failure groups and controls

\begin{tabular}{|c|c|c|c|c|c|}
\hline & $\begin{array}{l}\text { Acute HF } \\
(n=14)\end{array}$ & $\begin{array}{l}\text { Chronic com- } \\
\text { pensated HF } \\
(n=19)\end{array}$ & $\begin{array}{l}\text { Chronic decompensated } \\
\text { HF }(n=20)\end{array}$ & $\begin{array}{l}\text { Controls } \\
(n=13)\end{array}$ & $p$ value \\
\hline $\begin{array}{l}\text { Apelin }(\mathrm{pg} / \mathrm{mL}), \\
\text { median }(\mathrm{IQR})\end{array}$ & $\begin{array}{l}355 \\
(271-592)\end{array}$ & $\begin{array}{l}595 \\
(385-869)\end{array}$ & $\begin{array}{l}537.5 \\
(261-846)\end{array}$ & $\begin{array}{l}515 \\
(402-1005)\end{array}$ & 0.433 \\
\hline
\end{tabular}

$H F$ - heart failure, IQR - interquartile range.

and $515 \mathrm{pg} / \mathrm{mL}$ (IQR 402-1005 pg/mL) respectively, $p=0.223$.

In the HF patients group we found a significant association between apelin-13 and the NYHA class; NYHA class IV had the lowest apelin-13 level (250 pg/mL, IQR 225-270 pg/mL, $p=0.009$ ) (Figure 1). When the patients were analyzed according to the heart failure type, although not statistically significant, the acute HF group had the apelin-13 of all groups, as can be seen in Table 2 (all the groups were compared two by two).

Apelin-13 is negatively and strongly correlated with NT-proBNP level in HF group [Spearman's rho -0.83 , (95\% CI $-0.89--0.61), \mathrm{p}<0.001]$ and this correlation is maintained when all the subjects were analyzed [patients and controls, rho $-0.7,(95 \%$ CI $-0.74--0.44), p<0.001]$.

After adjusting initial values of apelin for age, gender, LDL and HDL cholesterol, and
BMI corrected clearance in a multiple linear regression, apelin remained statistically significant inversely associated with NT proBNP (the adjusted determination coefficient of the full model was 0.42 , and the unadjusted determination coefficient for apelin was 0.33) (Table 3).

Females had significantly lower levels of apelin-13 (372.5pg/mL, IQR 243.75-552.5pg/mL) compared with males $(617.5 \mathrm{pg} / \mathrm{mL}$ IQR 360 $902.5 \mathrm{pg} / \mathrm{mL}), p=0.027$.

Serum levels of HDL-cholesterol were weakly but statistically significant correlated with the level of apelin in the HF patients (Spearman's rho $0.27, p=0.048$ ).

The LV mass was $165.5 \pm 32.6 \mathrm{~g}(90.6 \pm$ $\left.17 \mathrm{~g} / \mathrm{m}^{2}\right)$ in the control group and $302.5 \pm 42 \mathrm{~g}$ $\left(162.5 \pm 41.1 \mathrm{~g} / \mathrm{m}^{2}\right)$ in the HF patients. All the controls had normal LV diameters, volumes and ejection fraction. In the HF group the LV end-diastolic volume was $161 \pm 67 \mathrm{ml}$. For the whole

Table 3. Multiple linear regression model of initial values of NT proBNP as dependent variable and apelin, adjusted for age, gender, LDL and HDL cholesterol, and creatinine clearance.

\begin{tabular}{llll}
\hline & Adjusted B & $\mathbf{( 9 5 \% ~ C I ) ~}$ & $\boldsymbol{p}$ \\
\hline Age (years) & 9.83 & $(-4.11-23.78)$ & 0.172 \\
\hline Sex (Male) & 98 & $(-187.33-383.33)$ & 0.503 \\
\hline LDL-cholesterol $(\mathrm{mg} / \mathrm{dL})$ & -3.56 & $(-6.73--0.38)$ & 0.032 \\
\hline HDL-cholesterol $(\mathrm{mg} / \mathrm{dL})$ & -4.69 & $(-16.04-6.66)$ & 0.421 \\
\hline Creatinine Clearance $\left(\mathrm{mL} / \mathrm{min} / 1,73 \mathrm{~m}^{2}\right)$ & 1.61 & $(-4.24-7.47)$ & 0.591 \\
\hline Apelin $(\mathrm{pg} / \mathrm{mL})$ & -0.56 & $(-0.84--0.29)$ & $<0.001$ \\
\hline
\end{tabular}

LDL- low density lipoprotein; HDL - high density lipoprotein; $C I$ - confidence index; Adjusted B adjusted regression coefficient. 
Table 4. The baseline characteristics of patients with Low and High Apelin-13 level.

\begin{tabular}{|c|c|c|c|c|}
\hline \multicolumn{2}{|l|}{ 年 } & $\begin{array}{l}\text { Low Ap13 } \\
(\mathrm{n}=27)\end{array}$ & $\begin{array}{l}\text { High Ap13 } \\
(\mathrm{n}=26)\end{array}$ & $\begin{array}{l}P \text { Val- } \\
\text { ue }\end{array}$ \\
\hline \multicolumn{2}{|l|}{ Age (years) } & $67.67(12.51)$ & $68.23(11.29)$ & 0.864 \\
\hline \multicolumn{2}{|l|}{ BMI $\left(\mathrm{kg} / \mathrm{m}^{2}\right)$} & $26.9(25.25-30.68)$ & $26.05(22.88-29.25)$ & 0.223 \\
\hline \multicolumn{2}{|l|}{ Sex (female) } & $12(44.44)$ & $3(11.54)$ & 0.008 \\
\hline \multicolumn{2}{|l|}{ Cigarette smoking } & $6(22.22)$ & $9(34.62)$ & 0.317 \\
\hline \multicolumn{2}{|l|}{ Alcohol drinking } & $3(11.11)$ & $7(26.92)$ & 0.175 \\
\hline \multirow{3}{*}{ Heart failure } & Acute (de novo) HF & $10(37.04)$ & $4(15.38)$ & \multirow{3}{*}{0.199} \\
\hline & Chronic compensated HF & $8(29.63)$ & $11(42.31)$ & \\
\hline & Chronic decompensated HF & $9(33.33)$ & $11(42.31)$ & \\
\hline \multirow{3}{*}{ NYHA class } & II & $9(33.33)$ & $16(61.54)$ & \multirow{3}{*}{0.003} \\
\hline & III & $9(33.33)$ & $10(38.46)$ & \\
\hline & IV & $9(33.33)$ & 0 & \\
\hline \multirow{4}{*}{ Medication } & Betablocker & 0 & $2(7.69)$ & \multirow{4}{*}{0.242} \\
\hline & ACE inhibitor & $8(29.63)$ & $3(11.54)$ & \\
\hline & Betablocker + ACE inhibitor & $13(48.15)$ & $15(57.69)$ & \\
\hline & None & $6(22.22)$ & $6(23.08)$ & \\
\hline \multicolumn{2}{|c|}{ LV end-diastolic volume (ml) } & $170(130-198.5)$ & $130(120-175)$ & 0.104 \\
\hline \multicolumn{2}{|c|}{ LV mass $\left(\mathrm{g} / \mathrm{m}^{2}\right)$} & $166.22(42.52)$ & $158.81(43.03)$ & 0.531 \\
\hline \multicolumn{2}{|c|}{ Ejection fraction (\%) } & $25(22.5-30)$ & $32.5(20-38.75)$ & 0.357 \\
\hline \multirow{3}{*}{$\begin{array}{l}\text { Mitral regurgita- } \\
\text { tion }\end{array}$} & absent/mild & $7(25.93)$ & $8(30.77)$ & \multirow{3}{*}{0.874} \\
\hline & moderate & $10(37.04)$ & $8(30.77)$ & \\
\hline & severe & $10(37.04)$ & $10(38.46)$ & \\
\hline \multirow{4}{*}{$\begin{array}{l}\text { Pulmonary arteri- } \\
\text { al hypertension }\end{array}$} & Absent & $11(40.74)$ & $14(53.85)$ & \multirow{4}{*}{0.652} \\
\hline & Mild & $6(22.22)$ & $6(23.08)$ & \\
\hline & Moderate & $8(29.63)$ & $4(15.38)$ & \\
\hline & Severe & $2(7.41)$ & $2(7.69)$ & \\
\hline \multicolumn{2}{|c|}{ QRS duration (msec) } & $120(80-135)$ & $115(80-140)$ & 0.805 \\
\hline \multicolumn{2}{|c|}{ NT-proBNP (pg/mL) } & $1531(1340-1737.5)$ & $889(616.7-1054)$ & $<0.001$ \\
\hline \multicolumn{2}{|c|}{ Uric acid $(\mathrm{mg} / \mathrm{dL})$} & $7.1(6.7-8.95)$ & $7.75(6.2-8.88)$ & 0.965 \\
\hline \multicolumn{2}{|c|}{ Total cholesterol $(\mathrm{mg} / \mathrm{dL})$} & $144(126.5-170.5)$ & $161.5(151.25-181.5)$ & 0.048 \\
\hline \multicolumn{2}{|c|}{$\begin{array}{l}\text { LDL-cholesterol (mg/dL) } \\
\text { HDL-cholesterol (mg/dL) }\end{array}$} & $83(71-104.5)$ & $98(79.25-105.25)$ & 0.152 \\
\hline HDL-cholesterol $(1$ & $\mathrm{mg} / \mathrm{dL})$ & $37(32.5-44)$ & $45(35.5-51.5)$ & 0.089 \\
\hline \multicolumn{2}{|c|}{ Triglycerides $(\mathrm{mg} / \mathrm{dL})$} & $102(78-145)$ & $112(91-141.75)$ & 0.488 \\
\hline \multicolumn{2}{|c|}{$\mathrm{C}$ reactive protein $(\mathrm{mg} / \mathrm{dL})$} & $0.6(0.5-1.27)$ & $0.5(0.23-0.6)$ & 0.071 \\
\hline \multicolumn{2}{|c|}{ Creatinine Clearance $(\mathrm{mL} / \mathrm{min})$} & $74.07(29.49)$ & $71.33(36.59)$ & 0.765 \\
\hline \multicolumn{2}{|c|}{ Corrected Creatinine Clearance $\left(\mathrm{mL} / \mathrm{min} / 1.73 \mathrm{~m}^{2}\right)$} & $66.57(22.34)$ & $64.7(29.9)$ & 0.797 \\
\hline
\end{tabular}

$B M I$ - body mass index; $H F$ - heart failure, $A C E$ inhibitor - angiotensin-converting-enzyme inhibitor; $L V$ - left ventricle; $L D L$ - low density lipoprotein; $H D L$ - high density lipoprotein. Categorical data are presented as number (percentage), normally distributed continuous data are presented as mean (standard deviation) and ones those not normally distributed are presented as median and interquartile range. 
study population the baseline LV mass was weakly correlated with the serum levels of apelin-13 (Speraman's rho 0.28, $p=0.023$ ). The rest of registered echocardiographic parameters had no significant influence on the apelin-13 level.

We tested the HF patients group for any other significant differences between males and females and we found that women had significantly lower LV mass than males; their values were lower by 60.29 (95\% CI 13.88-106.71, $p=0.012$ ) for the calculated LV mass and by 24.33 (95\% CI $0.15-48.52, p=0.049)$ for the indexed LV mass.

Fourthy-six percent of the females versus only $5.26 \%$ of the men were in NYHA IV class. In NYHA III class there were $33.33 \%$ of the females and $36.84 \%$ of the males, whereas $20 \%$ of the females and $57.89 \%$ of the males were in NYHA II class. The association between gender and NYHA class was statistically significant $(\mathrm{p}<0.001)$.

When divided into EF\% subgroups, NT-proBNP was significanlty lower in the group with $\mathrm{EF} \%>36 \%$ comparing with the other groups, $p=0.013$. The median NT-proBNP values were $403 \mathrm{pg} / \mathrm{mL}$ (IQR $303-1021 \mathrm{pg} / \mathrm{mL}$ ) for the $\mathrm{EF} \%>36 \%$ group, $1806 \mathrm{pg} / \mathrm{mL}$ (IQR 1603 $1881 \mathrm{pg} / \mathrm{mL})$ in the group with the EF\% between 30 and $35 \%, 1189 \mathrm{pg} / \mathrm{mL}$ (IQR $1060-1297 \mathrm{pg} / \mathrm{mL}$ ) for the group between $25-29 \%$ and $1536 \mathrm{pg} / \mathrm{mL}$ (IQR $1210-1536 \mathrm{pg} / \mathrm{mL}$ ) for the patients with $\mathrm{EF} \%<25 \%$. Apelin-13 values were similar in these groups.

\section{High and low Apelin-13 baseline comparisons}

The baseline characteristics of the Low and High Apelin-13 patient groups are described in Table 4. There were no significant differences in age, BMI, cigarette smoking, alcohol drinking and the medication used between the Low and High groups. A significantly greater number of females were found in the Low Apelin-13 $(p=0.008)$.
NT-proBNP is higher in Low Apelin-13 group (1531 pg/mL, IQR 1340-1737.5 pg/mL vs $889 \mathrm{pg} / \mathrm{mL}$, IQR 616.7-1054 pg/mL, $\mathrm{p}<0.001)$.

A significant difference between the two HF groups was noted for the total cholesterol level, being higher in the High apelin-13 group $(p=0.034)$. The fractions of serum cholesterol were not significantly different between the Low or High Ap13 groups.

\section{Follow-up assessment}

Twenty-seven patients were assessed at follow-up after an average time interval of 9 months. Eight patients died before the follow-up assessment, and these patients had lower baseline apelin-13 level compared to the patients who were assessed at follow-up $(395 \mathrm{pg} / \mathrm{mL}, \mathrm{IQR}$ 270-603 vs $275 \mathrm{pg} / \mathrm{mL}$, IQR 225-355 pg/mL) (Figure 2).

For the reassessed patients the median apelin-13 level was significantly higher at follow-up (460 pg/mL, IQR 342$871 \mathrm{pg} / \mathrm{mL}$ ) compared with the baseline level (395 pg/mL, IQR 270-603 pg/mL) (Wilcoxon paired test, $p=0.019$ ), and maintained the negative correlation with NT-proBNP level (Spearman's rho $-0.7, p<0.001$ ). There were no differences in the EF\% and NYHA class for the reassessed patients. NT-proBNP level was 1324.5 (IQR $1122-1428.24 \mathrm{pg} / \mathrm{mL}$ ) at baseline and $1175 \mathrm{pg} / \mathrm{mL}$ (IQR 984.5 - $1551 \mathrm{pg} / \mathrm{mL}$ ), $p=0.245$.

In the acute HF group the median baseline apelin was $355 \mathrm{pg} / \mathrm{mL}$ (IQR 271.25$592.5 \mathrm{pg} / \mathrm{mL})$ and it rose slightly at follow-up to $410 \mathrm{pg} / \mathrm{mL}(361.25-818.75 \mathrm{pg} / \mathrm{mL})$. We analyzed the changes in apelin-13 level for the BB/IECA naïve patients from the acute heart failure group: at baseline apelin-13 was $332.5 \mathrm{pg} / \mathrm{mL}$ (IQR 270-395 pg/mL) and it rose at follow-up to $687.5 \mathrm{pg} / \mathrm{mL}$ (IQR $395 \mathrm{pg} / \mathrm{mL}-988 \mathrm{pg} / \mathrm{mL}$ ), a difference of $355 \mathrm{pg} / \mathrm{mL}, p=0.875$ (Wilcoxon paired test). 


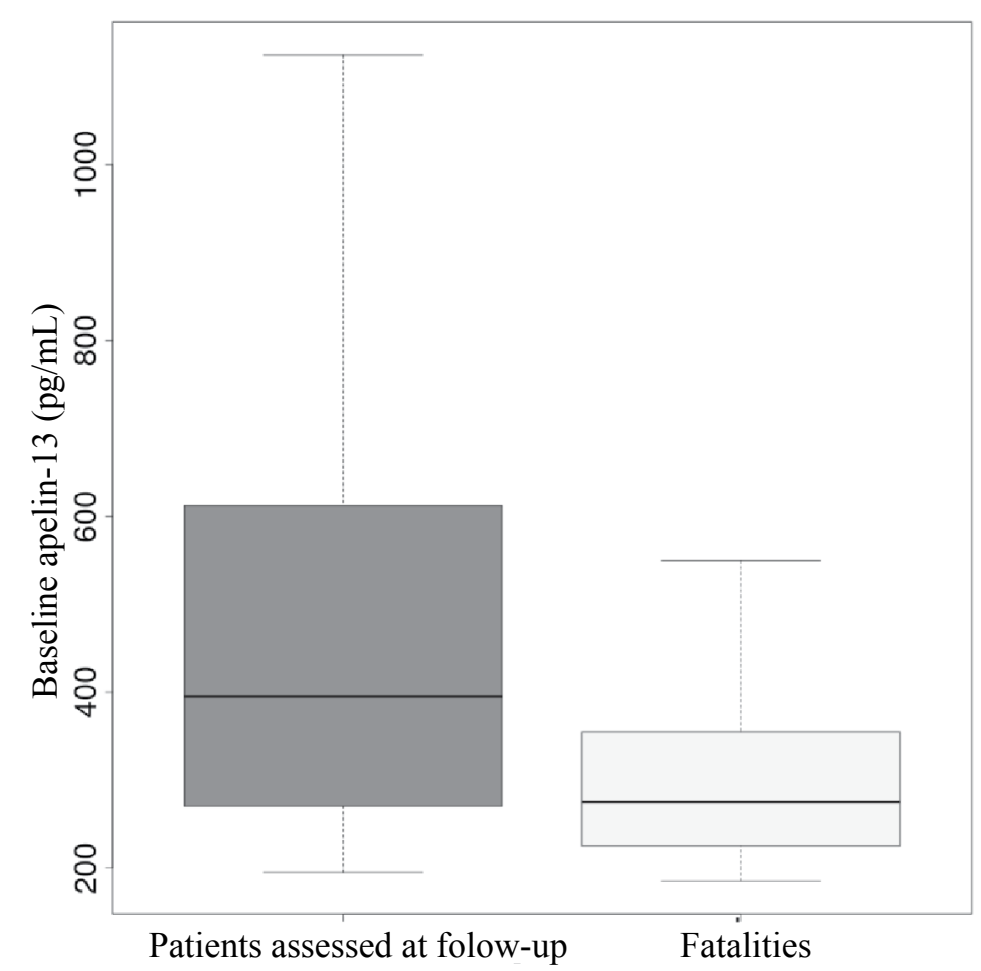

Figure 2. The relationship between baseline apelin-13 and NT-proBNP for all subjects.

\section{Discussion}

We chose to analyze the association between the serum levels of apelin-13 and NT pro-BNP in the heart failure patients in two different moments in their disease course, and compare it with a group of controls most of them already treated with beta-blocker and/or ACE inhibitors for essential arterial hypertension and with no alterations in LV systolic function. To our knowledge this is the first study investigating the dynamics of the serum apelin-13 level in the heart failure patients, whether it was a natural one or a therapeutically influenced one. Since the majority of heart failure patients receive neurohormonal treatment as part of their pharmacological long-term treatment, we tried to analyze the changes in serum level of apelin-13 and their potential correlations with betablocker and ACE inhibitor treatment.
We found out that the apelin-13 serum level of the chronic HF patients, whether they are compensated or decompensated, is similar with the controls, and this values are according to some of the data reported in literature [36]. All the chronic HF patients and most of the controls were already under treatment with betablokers and/or ACE inhibitors. Nevertheless, the samples being relatively small, this is not a proof of an absence of difference.

The acute HF patients, with $71 \%$ having no betablocker or ACE inhibitor treatment (the rest of them were only on ACE inhibitors for other indications), had lower baseline apelin-13 than all the other groups, and it was slightly increased at follow-up, after the initiation of medical treatment. The fact that the majority of patients who were reassessed at follow-up had a higher level of apelin-13 than the baseline suggests a benefi- 
cial influence of the medical treatment in the long term, but the absence of statistical significance and being an observational study does not permit us to advance a conclusion about this aspect.

The most important finding from our data is the negative, very strong correlation between serum levels of apelin-13 and NT-proBNP, which is in contradiction with other previous results [15], but in agreement with other scientific researches that showed lower apelin level in advanced heart failure, as well as with the theory that this decrease of serum apelin is negatively influenced by the course of the disease. Our findings showed that the Low apelin-13 group has higher NT-proBNP levels and also contains all the patients in NYHA IV class heart failure, 71\% of the acute HF patients, and 7 of 8 patients who died before follow-up. Although these last mentioned results have limited statistical power due to the small number of patients, they suggest a prognostic role of apelin, at least in theory, in the course of heart failure; the negative, very strong, correlation with the NT-proBNP level, which is already known as a very important prognostic biomarker for the heart failure patients, is a key element of this research that gives confidence for furthers studies to investigate the potential prognostic role of apelin-13 in this disease. Although there are larger experimental studies or reviews which reported no influence of apelin on prognosis, and especially on mortality, none of them used the apelin-13 fragment, which is the predominant form of the myocardial apelin in human plasma and cardiac tissue.

The strong correlation we observed between apelin-13 and NT-proBNP is a very important aspect, although the statistical significance was not obtained for the difference in apelin-13 level between heart failure patients versus controls. We consider this to be an important starting point for further research in order to establish the cut off value for apelin-13. As for NT-proBNP and BNP where different values have different meanings in acute versus chronic heart failure (the diagnostic values are much higher in acute than in chronic heart failure) or in the acute coronary syndrome (where the natriuretic peptides have a prognostic value), further research on larger groups should find significant differences.

All the patients with acute HF were started on betablockers and/or ACE inhibitors. The fact that median level of apelin-13 rose at follow-up for this group of patients and its level were not very different among the chronic HF patients, whether they were compensated or decompensated, might be a possible explanation on how the neurohormonal treatment is effective on improving the survival of HF patients, other than reducing the aldosterone, angiotensin II and catecholamines plasma levels, but this hypothesis needs to be investigated in further studies.

Another important result of our study is the significantly greater number of women in the Low Apelin-13 group. To our knowledge, there are no differences reported so far between genders, but already published studies either have a limited number of female subjects [15, 37-39], or the research focused mainly on male subjects $[13,40]$. The fact that there were no differences between genders other than apelin-13 level, NYHA class and LV mass and that apelin-13 was weakly correlated with LV mass when all subjects were analyzed (patients and controls) (Spearman's rho 0.28, $p=0.023$ ) give grounds for further research. The fact that the correlation between apelin-13 and LV mass was maintained in the whole study group limits the NYHA class influence on the apelin-13 level and reinforces the theory that the LV tissue is the main source for the serum level of this peptide.

Our study included a limited number of subjects and not all of them were assessed at follow-up and the statistical power of the test to detect differences can be low; therefore, the dy- 
namics of apelin-13 needs to be evaluated on a larger number of heart failures. The fact that the apelin-13 level was not significantly different between heart failure and control groups may be partially explained by the fact that $38.46 \%$ of the subjects in the control group had no neurohormonal treatment administered at the moment of inclusion.

In conclusion, we can state that apelin-13 was negatively correlated with NT-proBNP, both in the HF group and in the whole study population. The Low Apelin-13 group contained the majority of the patients with a negative outcome (death before follow-up), most of the patients who presented with acute HF and all the patients in NYHA IV class.

\section{Abbreviations}

ACE = Angiotensin converting enzyme

ANS = Adrenergic nervous system

APJ $=$ Apelin receptor

ASE = American Society of Echocardiography

BMI = Body mass index

$\mathrm{CV}=$ Coefficient of variability

$\mathrm{EF} \%=$ Ejection fraction

ELISA $=$ Enzyme linked immunosorbent assay

High Ap13 = Patients with apelin-13 level below the median value

HF $\quad=$ Heart failure

IL $1 \beta=$ Interleukin $1 \beta$

IQR = Interquartile range

Low Ap13 = Patients with apelin-13 level above the median value

LV = Left ventricle

NT-proB- $=$ N-terminal prohormone of brain

NP natriuretic peptide

NYHA $=$ New York Heart Association class class

$$
\begin{array}{ll}
\text { RAAS } & =\text { Renin-angiotensin-aldosterone } \\
& \text { system } \\
\text { SD } & =\text { Standard deviation } \\
\text { TNF } \alpha & =
\end{array}
$$

\section{References}

1. Stewart S, MacIntyre K, Hole DJ, Capewell S, McMurray JJ. More 'malignant' than cancer? Five-year survival following a first admission for heart failure. Eur J Heart Fail. 2001;3(3):315-22. DOI: 10.1016/S1388-9842(00)00141-0.

2. Mosterd A, Hoes AW. Clinical epidemiology of heart failure. Heart. 2007;93(9):1137-46. DOI: 10.1136/ hrt.2003.025270.

3. Hernandez AF, Greiner MA, Fonarow GC, Hammill BG, Heidenreich PA, Yancy CW, et al. Relationship between early physician follow-up and 30-day readmission among Medicare beneficiaries hospitalized for heart failure. JAMA. 2010;303(17):1716-22. DOI: 10.1001/jama.2010.533.

4. Bui AL, Horwich TB, Fonarow GC. Epidemiology and risk profile of heart failure. Nat Rev Cardiol. 2011;8(1):30-41. DOI: 10.1038/nrcardio.2010.165.

5. Aalbers J. New ESC heart failure guidelines with South African expert comment. Cardiovasc J Afr. 2012;23(5):295-6.

6. Roger VL. Epidemiology of heart failure. Circ Res. 2013;113(6):646-59. DOI: 10.1161/ CIRCRESAHA.113.300268.

7. Goidescu CM, Vida-Simiti LA. The Apelin-APJ System in the Evolution of Heart Failure. Clujul Med. 2015;88(1):3-8. DOI: 10.15386/cjmed-380.

8. Malyszko J, Malyszko JS, Pawlak K, Wolczynski S, Mysliwiec M. Apelin, a novel adipocytokine, in relation to endothelial function and inflammation in kidney allograft recipients. Transplant Proc. 2008;40(10):34669. DOI: 10.1016/j.transproceed.2008.03.163.

9. Malyszko J, Malyszko JS, Pawlak K, Mysliwiec M. Visfatin and apelin, new adipocytokines, and their relation to endothelial function in patients with chronic renal failure. Adv Med Sci. 2008;53(1):32-6. DOI: 10.2478/v10039-008-0024-x.

10. Vida-Simiti L, Todor I, Stoia M, Gherman C, Goidescu C. Plasma levels of resistin predicts cardiovascular events. RRML. 2014;22(1):35-47. DOI: 10.2478/rrlm2014-0011. 
11. Vida-Simiti LA, Todor I, Stoia MA, Goidescu CM, Anton FP, Farcas AD. Better prognosis in overweight/ obese coronary heart disease patients with high plasma levels of leptin. Clujul Med. 2016;89(1):65-71. DOI: $10.15386 /$ cjmed-524.

12. Szokodi I, Tavi P, Foldes G, Voutilainen-Myllyla S, Ilves $\mathrm{M}$, Tokola $\mathrm{H}$, et al. Apelin, the novel endogenous ligand of the orphan receptor APJ, regulates cardiac contractility. Circ Res. 2002;91(5):434-40. DOI: 10.1161/01.RES.0000033522.37861.69.

13. Foldes G, Horkay F, Szokodi I, Vuolteenaho O, Ilves M, Lindstedt KA, et al. Circulating and cardiac levels of apelin, the novel ligand of the orphan receptor APJ, in patients with heart failure. Biochem Biophys Res Commun. 2003;308(3):480-5. DOI: 10.1016/S0006291X(03)01424-4.

14. Emam MN, Abo El gheit RE. Promoting effect of adipocytokine, apelin, on hepatic injury in caerulein-induced acute pancreatitis in rats: Apelin on AP-induced hepatic injury. Alexandria Journal of Medicine. DOI: 10.1016/j.ajme.2015.11.003. DOI: 10.1016/j. ajme.2015.11.003.

15. Chong KS, Gardner RS, Morton JJ, Ashley EA, McDonagh TA. Plasma concentrations of the novel peptide apelin are decreased in patients with chronic heart failure. Eur J Heart Fail. 2006;8(4):355-60. DOI: 10.1016/j.ejheart.2005.10.007.

16. Zhang J, Ren CX, Qi YF, Lou LX, Chen L, Zhang LK, et al. Exercise training promotes expression of apelin and APJ of cardiovascular tissues in spontaneously hypertensive rats. Life Sci. 2006;79(12):1153-9. DOI: 10.1016/j.lfs.2006.03.040.

17. Koguchi W, Kobayashi N, Takeshima H, Ishikawa M, Sugiyama F, Ishimitsu T. Cardioprotective effect of apelin-13 on cardiac performance and remodeling in end-stage heart failure. Circ J. 2012;76(1):137-44. DOI: $10.1253 /$ circj.CJ-11-0689.

18. Soliman M, Arafah M. Apelin protect against multiple organ injury following hemorrhagic shock and decrease the inflammatory response. Int J Appl Basic Med Res. 2015;5(3):195-9. DOI: 10.4103/2229516X.165377.

19. Tasci I, Erdem G, Ozgur G, Tapan S, Dogru T, Genc H, et al. LDL-cholesterol lowering increases plasma apelin in isolated hypercholesterolemia. Atherosclerosis. 2009;204(1):222-8. DOI: $10.1016 / j$.atherosclerosis.2008.08.030.
20. Heinonen MV, Laaksonen DE, Karhu T, Karhunen L, Laitinen T, Kainulainen S, et al. Effect of diet-induced weight loss on plasma apelin and cytokine levels in individuals with the metabolic syndrome. Nutr Metab Cardiovasc Dis. 2009;19(9):626-33. DOI: 10.1016/j. numecd.2008.12.008.

21. Leal VO, Lobo JC, Stockler-Pinto MB, Farage NE, Calixto A, Geloneze B, et al. Apelin: a peptide involved in cardiovascular risk in hemodialysis patients? Ren Fail. 2012;34(5):577-81. DOI: 10.3109/0886022X.2012.668490.

22. Wang M, Gupta RC, Rastogi S, Kohli S, Sabbah MS, Zhang $\mathrm{K}$, et al. Effects of acute intravenous infusion of apelin on left ventricular function in dogs with advanced heart failure. J Card Fail. 2013;19(7):509-16. DOI: 10.1016/j.cardfail.2013.05.004.

23. Dai T, Ramirez-Correa G, Gao WD. Apelin increases contractility in failing cardiac muscle. Eur $\mathrm{J}$ Pharmacol. 2006;553(1-3):222-8. DOI: $10.1016 / j$. ejphar.2006.09.034.

24. Jia ZQ, Hou L, Leger A, Wu I, Kudej AB, Stefano J, et al. Cardiovascular effects of a PEGylated apelin. Peptides. 2012;38(1):181-8. DOI: 10.1016/j.peptides.2012.09.003.

25. Japp AG, Cruden NL, Barnes G, van Gemeren N, Mathews J, Adamson J, et al. Acute cardiovascular effects of apelin in humans: potential role in patients with chronic heart failure. Circulation. 2010;121(16):181827. DOI: 10.1161/CIRCULATIONAHA.109.911339.

26. Barnes GD, Alam S, Carter G, Pedersen CM, Lee KM, Hubbard TJ, et al. Sustained cardiovascular actions of APJ agonism during renin-angiotensin system activation and in patients with heart failure. Circ Heart Fail. 2013;6(3):482-91. DOI: 10.1161/ CIRCHEARTFAILURE.111.000077.

27. Masri B, Knibiehler B, Audigier Y. Apelin signalling: a promising pathway from cloning to pharmacology. Cell Signal. 2005;17(4):415-26. DOI: 10.1016/j.cellsig.2004.09.018.

28. Masri B, Morin N, Pedebernade L, Knibiehler B, Audigier Y. The apelin receptor is coupled to Gil or Gi2 protein and is differentially desensitized by apelin fragments. J Biol Chem. 2006;281(27):18317-26. DOI: 10.1074/jbc.M600606200.

29. Zhen EY, Higgs RE, Gutierrez JA. Pyroglutamyl apelin-13 identified as the major apelin isoform in human plasma. Anal Biochem. 2013;442(1):1-9. DOI: 10.1016/j.ab.2013.07.006. 
30. Maguire JJ, Kleinz MJ, Pitkin SL, Davenport AP. [Pyr1] apelin-13 identified as the predominant apelin isoform in the human heart: vasoactive mechanisms and inotropic action in disease. Hypertension. 2009;54(3):598-604. DOI: 10.1161/HYPERTENSIONAHA.109.134619.

31. McMurray JJ, Adamopoulos S, Anker SD, Auricchio A, Bohm M, Dickstein K, et al. ESC guidelines for the diagnosis and treatment of acute and chronic heart failure 2012: The Task Force for the Diagnosis and Treatment of Acute and Chronic Heart Failure 2012 of the European Society of Cardiology. Developed in collaboration with the Heart Failure Association (HFA) of the ESC. Eur J Heart Fail. 2012;14(8):803-69. DOI: 10.1093/eurjhf/hfs 105.

32. Lang RM, Badano LP, Mor-Avi V, Afilalo J, Armstrong A, Ernande L, et al. Recommendations for cardiac chamber quantification by echocardiography in adults: an update from the American Society of Echocardiography and the European Association of Cardiovascular Imaging. J Am Soc Echocardiogr. 2015;28(1):1-39 e14.

33. Foppa M, Duncan BB, Rohde LE. Echocardiographybased left ventricular mass estimation. How should we define hypertrophy? Cardiovasc Ultrasound. 2005;3:17. DOI: $10.1186 / 1476-7120-3-17$.

34. Armstrong AC, Gidding S, Gjesdal O, Wu C, Bluemke DA, Lima JA. LV mass assessed by echocardiography and CMR, cardiovascular outcomes, and medical practice. JACC Cardiovasc Imaging. 2012;5(8):837-48. DOI: $10.1016 /$ j.jcmg.2012.06.003.
35. R Core Team. R: A Language and Environment for Statistical Computing [Internet]. Vienna, Austria; 2015. Available from: http://www.r-project.org/.

36. Miettinen KH, Magga J, Vuolteenaho O, Vanninen EJ, Punnonen KR, Ylitalo K, et al. Utility of plasma apelin and other indices of cardiac dysfunction in the clinical assessment of patients with dilated cardiomyopathy. Regul Pept. 2007;140(3):178-84. DOI: 10.1016/j.regpep.2006.12.004.

37. Pitkin SL, Maguire JJ, Kuc RE, Davenport AP. Modulation of the apelin/APJ system in heart failure and atherosclerosis in man. $\mathrm{Br} \mathrm{J}$ Pharmacol. 2010;160(7):1785-95. DOI: $\quad 10.1111 / \mathrm{j} .1476-$ 5381.2010.00821.x.

38. Liu HT, Chen M, Yu J, Li WJ, Tao L, Li Y, et al. Serum apelin level predicts the major adverse cardiac events in patients with ST elevation myocardial infarction receiving percutaneous coronary intervention. Medicine (Baltimore). 2015;94(4):e449. DOI: 10.1097/ MD.0000000000000449.

39. Kuklinska AM, Sobkowicz B, Sawicki R, Musial WJ, Waszkiewicz E, Bolinska S, et al. Apelin: a novel marker for the patients with first ST-elevation myocardial infarction. Heart Vessels. 2010;25(5):363-7. DOI: 10.1007/s00380-009-1217-3.

40. Chandrasekaran B, Kalra PR, Donovan J, Hooper J, Clague JR, McDonagh TA. Myocardial apelin production is reduced in humans with left ventricular systolic dysfunction. J Card Fail. 2010;16(7):556-61. DOI: 10.1016/j.cardfail.2010.02.004. 